\title{
Cooling intake air of marine engine with water-fuel emulsion combustion by ejector chiller
}

\author{
Roman Radchenko ${ }^{1}$, Victoria Kornienko $^{1}$, Mykola Radchenko $^{1 *}$, Dariusz Mikielewicz ${ }^{2}$, Artem Andreev ${ }^{1}$, Ivan \\ Kalinichenko ${ }^{1}$ \\ ${ }^{1}$ Admiral Makarov National University of Shipbuilding, 9 Heroes of Ukraine Avenue, Mykolayiv, Ukraine \\ ${ }^{2}$ Gdańsk University of Technology, 11/12 Gabriela Narutowicza Street, 80-233 Gdansk, Poland
}

\begin{abstract}
The fuel efficiency of cooling air at the inlet of marine low speed diesel engine with water-fuel emulsion combustion by ejector chiller utilizing the heat of exhaust gas along the route line MariupolAmsterdam-Mariupol was estimated. The values of available refrigeration capacity of ejector chiller, engine intake air temperature drop and corresponding decrease in specific fuel consumption of the main diesel engine at varying climatic conditions along the route line were evaluated. Their values for water-fuel emulsion were compared with conventional fuel oil combustion.
\end{abstract}

\section{Introduction}

Low speed diesel engines are the most widespread as ship main engines [1]. The variation in ambient air temperatures along the route line influences the fuel efficiency of the engines. Thus, an increase in engine intake air temperature by $10^{\circ} \mathrm{C}$ causes specific fuel consumption increase by 1.1 to $1.2 \mathrm{~g} /(\mathrm{kWh})$ [2]. In the most cases at the main engine load above $50 \%$ an exhaust gas heat utilized by the exhaust gas boiler exceeds the ship steam demand. It is reasonably to use "surplus" exhaust heat by ejector chiller (ECh) as the most simple in design $[3,4]$ for engine intake air cooling (EIAC) to improve fuel efficiency [5, 6].

The efficiency of water-fuel emulsion (WFE) combustion is increased compared with fuel oil combustion due to microexplosions of WFE droplets, that intensifies the processes of mixing fuel with air and combustion in the whole. With this the enhanced fragmentation of WFE droplets leads to reduction of the particle emission.

Despite the increased humidifying the surface with an increase of the water content to about $10 \%$, due to enhanced fragmentation of WFE droplets and entrainment of small particles by the exhaust gas flow, the intensity of their deposition decreases. Thus, the deposits can be easily removed (e.g. by washing).

\section{Literature review}

A lot of researches are devoted to enhancing the fuel efficiency of combustion engines [7, 8] by cooling cyclic air $[9,10]$ in waste heat recovery chillers [11]. The absorption lithium-bromide chillers (ACh) are the most widely used and provide cooling air to about $15^{\circ} \mathrm{C}$ with a high coefficient of performance COP of 0.7 to
0.8. But because of large sizes the ACh units mounting in engine room is problematical. The ECh consist of heat exchangers [12] suitable for mounting in free spaces. They enables to deep cool air but with a low COP of 0.2 to 0.3 [13] and quite suitable for railway $[14,15]$ and marine $[16,17]$ applications.

The heat loss with exhaust gases represents a high part of the total waste heat in combustion engines [18, 19]. Authors [20] introduced the technique of exhaust gas heat utilization in gas cogeneration unit based on absorption heat exchange. The low-temperature economizers [21] or low-pressure economizers [22] use a condensation heat of vapors of sulfuric acid and water in exhaust gas. The condensed acid vapor glues the ash in exhaust gas, and adheres on heating surface [23], which increases the hydraulic and thermal resistance [24], affecting the reliable and economical operation. The experience of using WFE in boilers and diesel engines indicates the undeniable advantages of this type of fuel: the effective specific fuel consumption decreases by about $8 \%$ [25], in the exhaust gases the concentration of nitrogen oxides is reduced in 1.4 to 3.1 times [26], the concentration of $\mathrm{CO}-$ in 1.3 to 1.5 times [27], smoke - in 1.3 to 2.4 times [28]. The influence of WFE combustion process parameters in low capacity boiler on the level of formation of nitrogen oxides, carbon monoxide and soot was studied [27]. The analysis of literary sources shows, that there is no quantitative data of low-temperature corrosion [29, 30] (LTC intensity of condensation low-temperature heating surfaces (LTHS) of EGB while WFE combustion.

A double effect is achieved with WFE combustion: enhanced fragmentation of WFE droplets due to their microexplosions intensifies the combustion processes and reduces the particle emission as result, as well as intensifies entrainment of small particles by the exhaust

* Corresponding author: nirad50@gmail.com 
gas flow and decreases their deposition on condensing/heating economizer surfaces and their thermal resistance as result $[31,32]$.

The aim of the research is to develop a marine engine intake air cooling (EIAC) system with deep utilization of the exhaust gas heat potential enlarged due to using the heat of low-temperature condensation of vapors of sulfuric acid and water when WFE combustion as a novel trend in ship waste heat recovery.

The research tasks:

- to carry out the experimental research of lowtemperature condensation economizer to receive the data on corrosion when WFE combustion;

- to develop a marine engine intake air cooling system with deep utilization of the exhaust gas heat when WFE combustion;

- to estimate the fuel efficiency of cooling the intake air of marine low speed diesel engine with WFE combustion by ECh compared with fuel oil combustion on the ship route line.

\section{Research methodology}

\subsection{Experimental research}

Investigations of corrosion intensity of low-temperature condensation economizer were carried out on an experimental setup (Fig. 1, a) with fuel oil and WFE based on this fuel oil combustion $[33,34]$ with different water content with an almost constant excess air ratio.

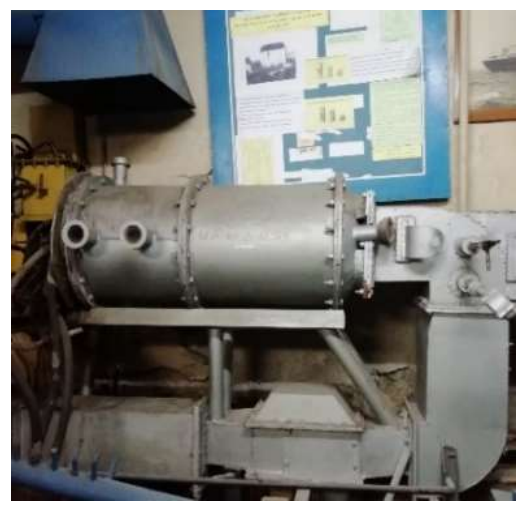

$a$

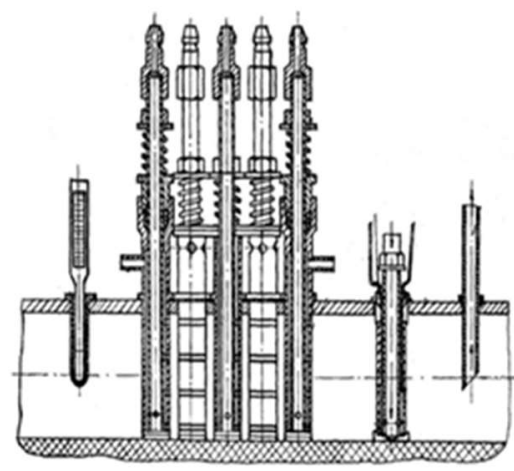

$b$

Fig.1. General view of the experimental setup (a) and tubesamples of low-temperature condensation economizer (b).
Based on experimental studies the minimum value of wall temperature is defined (Fig. 2, a), at which the permissible speed of low-temperature corrosion at a level of $0.25 \mathrm{~mm} /$ year and the minimum value of exhaust gas temperature at exit from EGB are ensured (Fig. 2, b). Fig. 2, b show that the smallest values of corrosion intensity are observed for large values of water content in water-fuel emulsion $30 \%$.
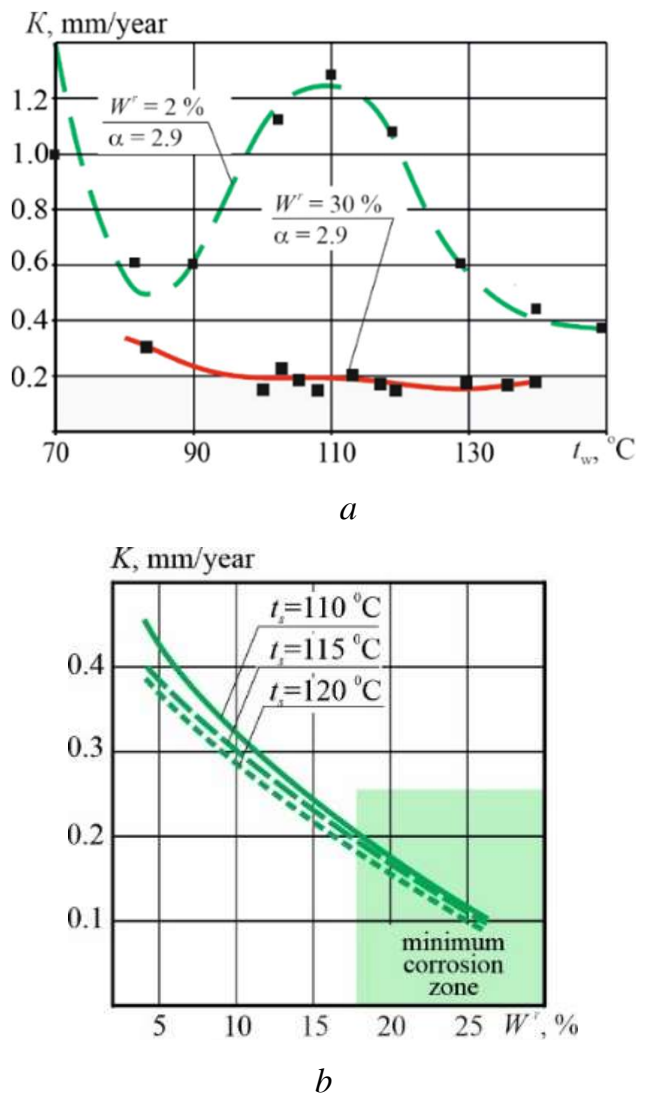

Fig. 2. Dependences of corrosion rate of low-temperature condensation economizer on the wall temperature $K=f\left(t_{w}\right)$ (a) and water content $W^{r}$ in emulsion (b).

The range of wall temperature within $90^{\circ} \mathrm{C}$ down to $70^{\circ} \mathrm{C}$ of low-temperature condensation economizer (LTCE) safe operation is determined, which reveals the potential for deep exhaut gas heat utilization as compared with $150^{\circ} \mathrm{C}$ down to $130^{\circ} \mathrm{C}$ for conventional fuel oil combustion.

\subsection{Theoretical research}

A schema of cooling intake ambient air at the suction of turbocharger of diesel engine by utilizing the heat of exhaust gas in evaporative and economizer section of generator is shown in Fig. 3. The ejector refrigeration machine consists of power and refrigeration contours. A generator of power contour uses a heat of exhaust gas to produce a high pressure refrigerant vapour as a motive fluid which energy is used in ejector to compress the low pressure refrigerant vapour, sucked from evaporatorintake air cooler of refrigeration contour, up to the pressure in the condenser.

As an example of transport vessel a bulk carrier with low speed diesel engine 5S60ME-C10.5-TIII as the main engine [2] is considered: nominal power $N_{\mathrm{n}}=$ 
$12450 \mathrm{~kW}$ and continuous service power $N_{\mathrm{s}}=10580 \mathrm{~kW}$. A decrease in temperature of air $\Delta t_{\mathrm{a}}$ at the engine inlet due to its cooling by ECh and, accordingly, effect from its application depends on the heat of steam produced by exhaust heat utilization steam boiler (Exh.SB), that remains after covering all the heat requirements aboard ship. During warm time steam consumption on the transport ship is approximately $25 \%$ of steam productivity of exhaust boiler, i.e. $75 \%$ of steam produced can be used in ECh for cooling of air at the inlet of diesel engine turbocharger.

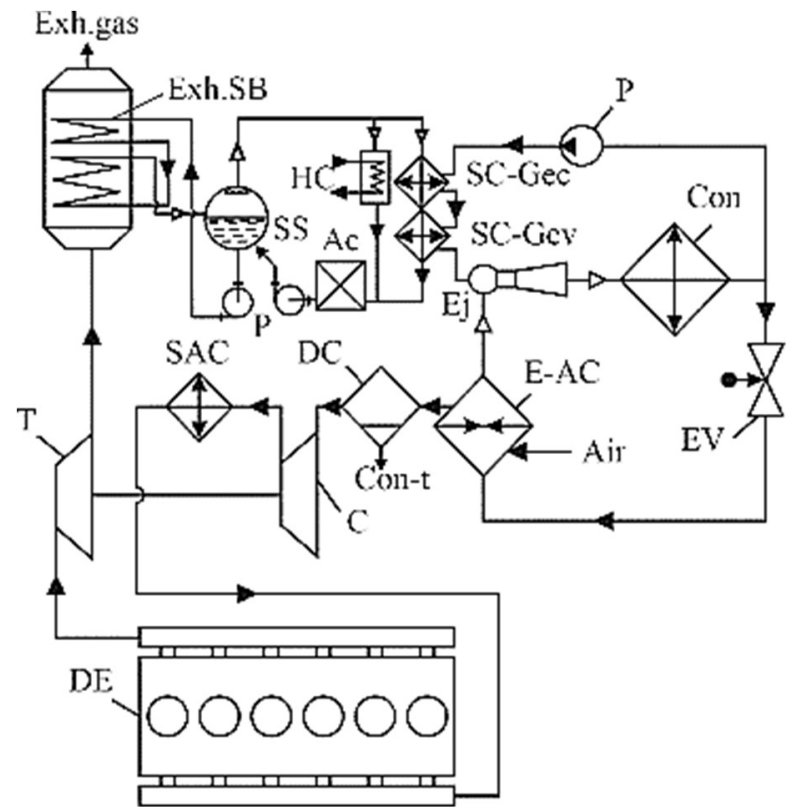

Fig. 3. Schema of system for cooling intake air at the suction of turbocharger by utilizing the heat of exhaust gas: DE diesel engine; $\mathrm{T}$ - turbine, $\mathrm{C}$ - compressor of turbocharger; SAC - scavenge air cooler; Exh.SB - exhaust gas steam boiler; SC-Gev - steam condenser-evaporative section of generator; $\mathrm{Gec}$ - economizer section of generator; E-AC evaporator-air cooler; $\mathrm{Ej}$ - ejector; Con - condenser; EV expansion valve; $\mathrm{P}$ - pump; Con- $\mathrm{t}$ - condensate; $\mathrm{DC}$ droplet catcher; Ac - accumulator of feed water; SS - steam separator; $\mathrm{HC}$ - heat consumer. $\mathrm{CE}$ - condensation economizer.

Besides, decrease in temperature of air in the air cooler at the inlet of the engine $\Delta t_{\mathrm{a}}=t_{\mathrm{a} 1}-t_{\mathrm{a} 2}$ depends on the temperature $t_{\mathrm{a} 1}$ and relative humidity $\varphi_{\mathrm{a}}$ of intake air in the engine room, in turn, depending on parameters of ambient air, i.e. sailing environmental conditions. During sailing in warm time the air temperature in the engine room $t_{\mathrm{ER}}$ exceeds ambient temperature by $10{ }^{\circ} \mathrm{C}$ [2].

The temperature $t_{\mathrm{a} 2}$ which limits depth of cooling air in the air cooler, in turn, depends on the temperature of boiling refrigerant. In case of application of ECh a refrigerant R142b can be used. A temperature of boiling $\mathrm{R} 142 \mathrm{~b}$ in the evaporator-air cooler is desirable about $t_{0}=7^{\circ} \mathrm{C}$.

The minimum difference of temperatures between cooled air and boiling refrigerant can be accepted $8{ }^{\circ} \mathrm{C}$. Taking into account these values a depth of cooling of air in the air cooler is limited to minimum temperature $t_{\mathrm{a} 2}=t_{0}+8=15^{\circ} \mathrm{C}$. A refrigeration capacity of $\mathrm{ECh}$ $Q_{0}$ is defined from available exhaust gas heat $Q_{\mathrm{G}}$ as
$Q_{0}=\zeta Q_{\mathrm{G}}$, where $\zeta-$ coefficient of performance of ECh $\zeta=0.30 \ldots 0.35$.

\section{Results}

A route line Mariupol-Amsterdam-Mariupol is considered. Values of temperature $t$ and relative humidity $\varphi$ of ambient air, and also sea water temperature $t_{\mathrm{w}}$ during route were used according to the meteocenter data, fixed each 3 hours. Values of moist content $d_{\mathrm{a}}$ following them were calculated (Fig. 4).

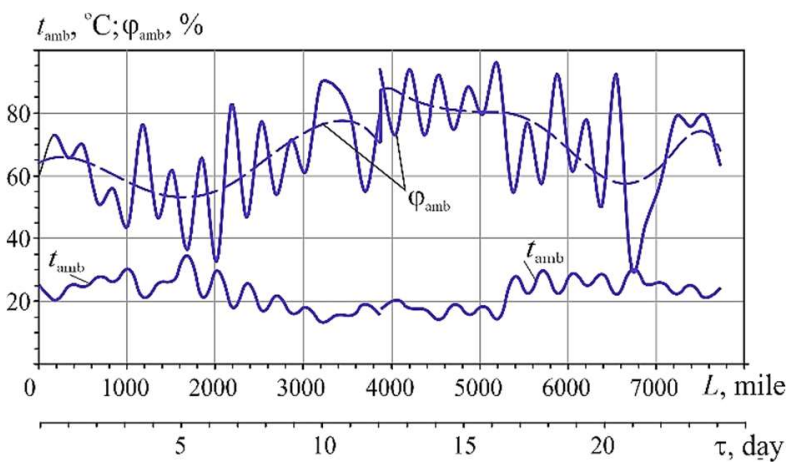

Fig. 4. Variation of ambient air temperature $t_{\mathrm{amb}}$, relative humidity $\varphi_{a m b}$ and absolute humidity $d_{\mathrm{a}}$, on the route line Mariupol-Amsterdam-Mariupol (22.07.2019...3.08.2019).

As one can see, during summer route the temperature of ambient air $t_{\mathrm{amb}}$ changes from $15 \ldots 20^{\circ} \mathrm{C}$ in middle widths to $25 \ldots 30^{\circ} \mathrm{C}$ in southern widths (accordingly air temperature in engine room is $10^{\circ} \mathrm{C}$ higher), and relative humidity of air $\varphi_{\mathrm{amb}}$ - from $50 \ldots 60 \%$ in Mediterranean sea to $80 \ldots 90 \%$ at Northwest Europe.

For each time interval ( 3 hours) and corresponding temperature $t_{\mathrm{amb}}$ and relative humidity $\varphi_{\mathrm{amb}}$ of ambient air the processes of cooling of intake air in the air cooler at the inlet of diesel engine from the air temperature at the cooler inlet (in engine room) $t_{\mathrm{a} 1}=t_{\mathrm{amb}}+10^{\circ} \mathrm{C}$ to the outlet air temperature $t_{\mathrm{a} 2}$ were calculated.

In the case of using the enlarged exhaust gas heat when WFA combustion the values of the available cooling capacity $\mathrm{Q}_{0 \mathrm{WFA}}$ of ECh is higher compared with $\mathrm{Q}_{0}$ for fuel oil combustion due to deeper exhaust gas heat utilization to lowered temperatures $t_{\text {exh2 }}=$ $90 \ldots 110^{\circ} \mathrm{C}$ compared with $t_{\operatorname{exh} 2}=150 \ldots 170^{\circ} \mathrm{C}$ (Fig. 5).

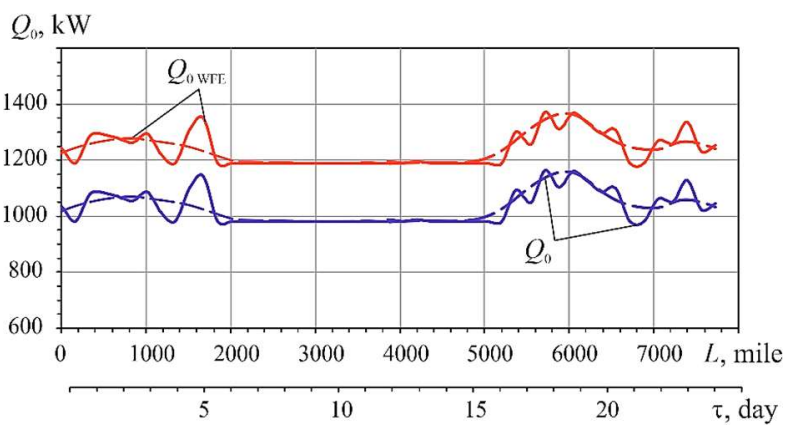

Fig.5. The available cooling capacities of ECh: $\mathrm{Q}_{0}$ - fuel oil; Q 0 WFE - WFE.

Accordingly the values of air temperature drop at the engine inlet $\Delta t_{\mathrm{a}}$ when WFE combustion $\Delta t_{\mathrm{aWFE}}$ are higher compared with oil fuel $\Delta t_{\mathrm{a}}$ (Fig.6). 


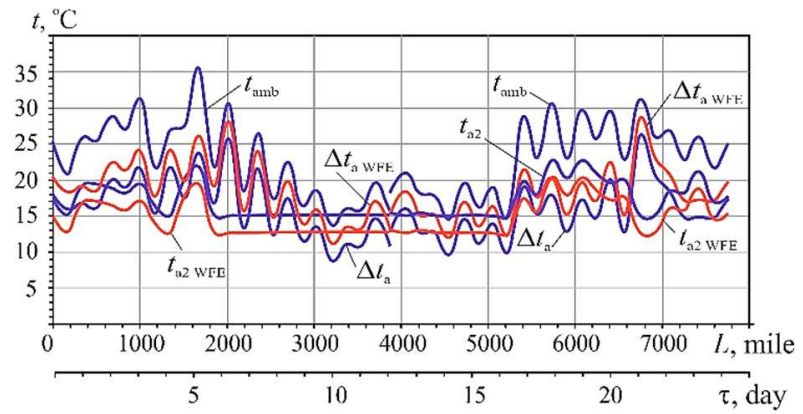

Fig. 6. The values of engine intake air temperature drop: $\Delta t_{\mathrm{a}}-$ fuel oil; $\Delta t_{\mathrm{a}}-\mathrm{WFE}$.

As it is shown, decrease in temperature of air in the air cooler of ECh, utilizing a heat of exhaust gas (schema in Fig. 3) $\Delta t_{\mathrm{a}}=10 \ldots 20^{\circ} \mathrm{C}$ when oil fuel combustion whereas $\Delta t_{\mathrm{a}}=15 \ldots 25^{\circ} \mathrm{C}$ for WFE.

Decrease in specific fuel consumption $\Delta b_{e}$, $\mathrm{g} /(\mathrm{kW} \cdot \mathrm{h})$, of diesel engine, saving of fuel consumption in absolute $B_{e}, \mathrm{t}$, and relative $B_{e}^{\prime}, \%$, values on the route line Mariupol-Amsterdam-Mariupol due to cooling intake air by ejector refrigeration machine, using exhaust gas heat only (schema in Fig. 1), and by sea water, calculated by program "mandieselturbo" [2], are shown in Fig. 7.

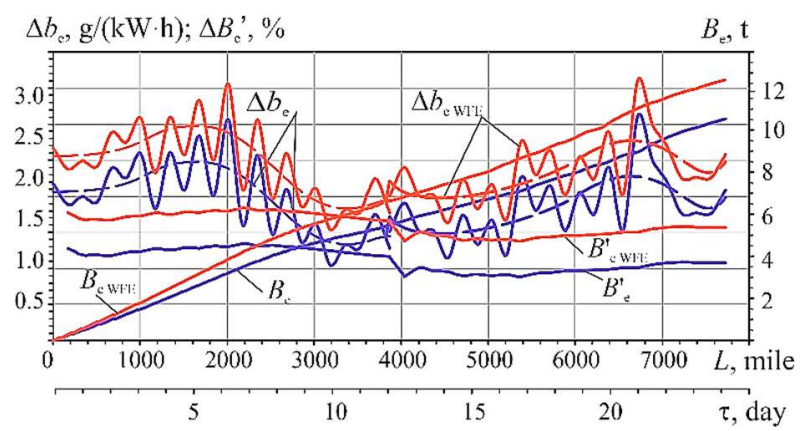

Fig. 7. Decrease of specific fuel consumption $\Delta b_{e}, \mathrm{~g} /(\mathrm{kWh})$, fuel saving in absolute $B_{e}, \mathrm{t}$, and relative $B^{\prime}{ }_{e}, \%$, values on the route line Mariupol-Amsterdam-Mariupol (22.07.2019...3.08.2019): $\Delta b_{e}, B_{e}$ and $B_{e}^{\prime}-$ oil fuel; $\Delta b_{\mathrm{e}} \mathrm{WFE}, B_{e} \mathrm{WFE}$ and $B_{e}^{\prime} \mathrm{WFE}-\mathrm{WFE}$.

As one can see, a decrease of specific fuel consumption due to intake air cooling by $\mathrm{ECh}$, using exhaust gas heat, $\Delta b_{\mathrm{e}}=1.2 \ldots 2.5 \mathrm{~g} /(\mathrm{kW} \cdot \mathrm{h})$, absolute fuel saving $B_{e} \approx 10 \mathrm{t}$ and relative fuel saving $B^{\prime}{ }_{e}=$ $1.2 \ldots 1.3 \%$ for oil fuel combustion, whereas $\Delta b_{\mathrm{e}}=$ $1.2 \ldots 2.5 \mathrm{~g} /(\mathrm{kW} \cdot \mathrm{h}), \quad B_{e \mathrm{WFE}} \approx 10 \mathrm{t} \quad$ and $\quad B_{e \mathrm{WFE}}^{\prime}=$ $1.2 \ldots 1.3 \%$ for WFE combustion in diesel engine5S60ME-C10.5-TIII on the route line MariupolAmsterdam-Mariupol (22.07.2019...3.08.2019).

The further reserves to increase fuel saving by about 1.5 times consist in complex engine intake and scavenge air cooling with using additional heat of scavenge air in ECh or in combined absorption-ejector chiller wit ACh as a high-temperature stage to cool the air to about $15^{\circ} \mathrm{C}$ and its deep subcooling to $10^{\circ} \mathrm{C}$ and lower in the case of engine intake air.

\section{Conclusions}

A marine engine intake air cooling system with deep utilization of the exhaust gas heat potential enlarged due to using the heat of low-temperature condensation of vapors of sulfuric acid and water in economizer section of ejector chiller generator when water-fuel emulsion combustion is developed as a novel trend in ship waste heat recovery.

The results of experimental research of lowtemperature condensation economizer approved the appropriate corrosion rate when water-fuel emulsion combustion and good perspective for their application in ship waste heat recovery.

The application of developed diesel engine intake air cooling system provides 1.3 to $1.7 \%$ fuel saving on the route line Mariupol-Amsterdam-Mariupol and reveals a good perspectives for increasing the fuel saving by 1.5 times due to complex engine intake and scavenge air cooling through using additional heat of scavenge air in ECh or in combined absorption-ejector chiller.

\section{References}

1. V. Kornienko, M. Radchenko, R. Radchenko, D. Konovalov, A. Andreev, M. Pyrysunko, Improving the efficiency of heat recovery circuits of cogeneration plants with combustion of water-fuel emulsions. Thermal Science 25 (1 Part B), 791800 (2021)

2. MAN Diesel Turbo, CEAS Engine Calculations [Online], available at: https://marine.manes.com/two-stroke/ceas. 2019

3. D. Butrymowicz, J. Gagan, K. Śmierciew, M. Łukaszuk, A. Dudar, A. Pawluczuk, A. Łapiński, A. Kuryłowic, Investigations of prototype ejection refrigeration system driven by low grade heat, in E3S Web of Conferences 70, 7 p. (2018)

4. D. Konovalov, H. Kobalava, V. Maksymov, R. Radchenko, M. Avdeev, Experimental research of the excessive water injection effect on resistances in the flow part of a low-flow aerothermopressor, in Advances in Design, Simulation and Manufacturing III (DSMIE 2020). LNME, pp. 292-301 (2020)

5. M. Radchenko, D. Mikielewicz, A. Andreev, S. Vanyeyev, O. Savenkov, Efficient ship engine cyclic air cooling by turboexpander chiller for tropical climatic conditions, in Integrated Computer Technologies in Mechanical Engineering (ICTM 2020), LNNS, 188, pp. 498507 (2021)

6. A. Radchenko, E. Trushliakov, V. Tkachenko, B. Portnoi, O. Prjadko, Improvement of the refrigeration capacity utilizing for the ambient air conditioning system, in Advanced Manufacturing Processes II, InterPartner 2020, LNME, pp. 714723 (2021)

7. R. Radchenko, M. Pyrysunko, A. Radchenko, A. Andreev, V. Kornienko, Ship engine intake air cooling by ejector chiller using recirculation gas heat, in Advanced Manufacturing Processes. InterPartner-2020, LNME, pp. 734-743 (2021).

8. R. Radchenko, M. Pyrysunko, V. Kornienko, I.-C. Scurtu, R. Patyk, Improving the ecological and 
energy efficiency of internal combustion engines by ejector chiller using recirculation gas heat, In Integrated Computer Technologies in Mechanical Engineering (ICTM 2020), LNNS, 188, pp. 531541 (2021)

9. A. Radchenko, A Stachel, S. Forduy, B. Portnoi, O. Rizun, Analysis of the efficiency of engine inlet air chilling unit with cooling towers, in Advances in Design, Simulation and Manufacturing III (DSMIE 2020), LNME, pp. 322-331 (2020)

10. M. Radchenko, M. Radchenko, A. Radchenko, R. Radchenko, S. Kantor, D. Konovalov, V. Kornienko, Rational loads of turbine inlet air absorption-ejector cooling systems, Proceedings of the Institution of Mechanical Engineers, Part A: Journal of Power and Energy (2021). https://doi.org/10.1177/09576509211045455

11. A. Radchenko, E. Trushliakov, K. Kosowski, D. Mikielewicz, M. Radchenko, Energies 13, 6201 (2020)

12. E. Trushliakov, A. Radchenko, S. Forduy, A. Zubarev, A. Hrych, Increasing the operation efficiency of air conditioning system for integrated power plant on the base of its monitoring, in Integrated Computer Technologies in Mechanical Engineering (ICTM 2019), AISC, 1113, pp. 351360 (2020)

13. T. Bohdal, W. Kuczynski, Heat Transf. Eng. 32, 359 (2011)

14. M. Radchenko, R. Radchenko, V. Tkachenko, S. Kantor, E. Smolyanoy, Increasing the operation efficiency of railway air conditioning system on the base of its simulation along the route line, in Integrated Computer Technologies in Mechanical Engineering (ICTM 2019), AISC, 1113, pp. 461467 (2020)

15. N. Radchenko, E. Trushliakov, A. Radchenko, A. Tsoy, O. Shchesiuk, Methods to determine a design cooling capacity of ambient air conditioning systems in climatic conditions of Ukraine and Kazakhstan, in AIP Conference Proceedings 2285, 030074 (2020)

16. E. Trushliakov, A. Radchenko, M. Radchenko, S. Kantor, O. Zielikov, The Efficiency of refrigeration capacity regulation in the ambient air conditioning system, in Advances in Design, Simulation and Manufacturing III (DSMIE 2020), LNME, pp. 343-353 (2020)

17. M. Radchenko, D. Mikielewicz, V. Tkachenko, M. Klugmann, A. Andreev, Enhancement of the operation efficiency of the transport air conditioning system, in Advances in Design, Simulation and Manufacturing III (DSMIE 2020), LNME, pp. 332-342 (2020)

18. C. Luo, K. Luo, Y. Wang, Z. Ma, Y. Gong, Energy Procedia 105, 3045 (2017)

19. Syed Safeer Mehdi Shamsi, Assmelash A. Negash, Gyu Baek Cho, Young Min Kim, Sustainability 11(7), 1881 (2019)
20. F. Li, L. Duanm, L. Fu, X. Zhao, Procedia Eng. 146, 594 (2016).

21. S. Baldi, T.L. Quang, O. Holub, P. Endel, Energy Conversion and Management 136, 329 (2017)

22. C. Fan, D. Pei, H. Wei, Energy Convers. Manag. 171, 1388 (2018)

23. Y.C. Miao, C.L. Yu, B.H. Wang, K. Chen, Advanced Materials Research 779, 469 (2013)

24. D.A. Sugeng, A.M. Ithnin, N.S.M.S. Amri, M.A. Ahmad, W.J. Yahya, Journal of Advanced Research in Fluid Mechanics and Thermal Sciences 49(1), 62 (2017)

25. P. Baskar, A. Senthil Kumar, Alexandria Engineering Journal 56(1), 137 (2017)

26. K.R. Patel, V. Dhiman, International Journal of Latest Engineering Research and Applications 2(9), 37 (2017)

27. M.K. Wojs, P. Orliński, W. Kamela, P. Kruczyński, Research on the influence of ozone dissolved in the fuel-water emulsion on the parameters of the CI engine, in IOP Conference Series: Materials Science and Engineering, 148, pp. 1-8 (2016)

28. R.K. Gupta, K.A. Sankeerth, T.K. Sharma, G. Rao, K.M. Murthy, Applied Mechanics and Materials 592, 1526 (2014)

29. L. Bohdal, L. Kukielka, A.M. Radchenko, R. Patyk, M. Kułakowski, J. Chodór, Modelling of guillotining process of grain oriented silicon steel using FEM, in AIP Conference Proceeding, 2078, 020080 (2019)

30. L. Bohdal, L. Kukiełka, S. Legutko, R. Patyk, A.M. Radchenko, Materials 13, 3175 (2020)

31. V. Kornienko, R. Radchenko, T. Bohdal, M. Radchenko, A. Andreev, Thermal characteristics of the wet pollution layer on condensing heating surfaces of exhaust gas boilers, in Advances in Design, Simulation and Manufacturing IV (DSMIE 2021), LNME, pp. 339-348 (2021)

32. V. Kornienko, R. Radchenko, Ł. Bohdal, L. Kukiełka, S. Legutko, Investigation of condensing heating surfaces with reduced corrosion of boilers with water-fuel emulsion combustion, in Integrated Computer Technologies in Mechanical Engineering (ICTM 2020), LNNS, 188, pp. 300309 (2021)

33. V. Kornienko, R. Radchenko, D. Konovalov, A. Andreev, M. Pyrysunko, Characteristics of the rotary cup atomizer used as afterburning installation in exhaust gas boiler flue, in Advances in Design, Simulation and Manufacturing III (DSMIE 2020), LNME, pp. 302-311 (2020)

34. V. Kornienko, R. Radchenko, D. Mikielewicz, M. Pyrysunko, A. Andreev, Improvement of characteristics of water-fuel rotary cup atomizer in a boiler, in Advanced Manufacturing Processes. InterPartner-2020, LNME, pp. 664-674 (2021) 